\title{
Consumers' Demographic Differences and the Country-of-Origin Effects on Evaluations of Product Categories: An International Study
}

\author{
A Ben Oumli1*, Karen L Koza, Richard Montague \\ Western Connecticut State University, Danbury, USA \\ *Corresponding Author
}

\begin{abstract}
The aim of this study is to fill in a gap in Country-of-Origin (COO) studies by assessing the relationship between $\mathrm{COO}$ and consumer decision-making processes in Morocco, an emerging market, and non-Western Mediterranean country and culture. Specifically, this research study demonstrates that the consumer demographic characteristic of age does make a difference in the COO influence for product categories within Morocco. Age was shown to interact with the impact of $\mathrm{COO}$ with regard to purchasing decisions regarding products from more industrialized/economically advanced nations, compared to products from less economically advanced/industrialized nations. These results have managerial implications in assisting multinational organizations in their market segmentations and positioning strategies.
\end{abstract}

Keywords: Country of Origin, International, International Consumer Behavior, Cross-Cultural, Morocco

\section{Introduction}

The product category is an important element of COO (de Mooij, 2004). Consumer behavior regarding COO knowledge varies by product category (Fetscherin and Toncar, 2010; Tigli et al., 2010; Manrai et al., 1998; Balabanis and Diamantopoulos, 2004) and attributes (Eroglu and Machleit, 1989).For example, as previous research has revealed, consumers may relate fashionable clothing with France and quality automobiles with Germany, but not relate well-crafted cameras with either nation. Tigli et al. (2010) assessed the country-of-origin effect within the context of Turkish consumers. The aim was to search how consistent the Turkish consumers are in perceiving some products/product categories and the countries those products are associated with. The findings showed that participants were not consistent in associating the names of the product categories and the names of the countries with each other.

Bandyopadhyay and Bnerjee's (2002) study analyzed Indian consumer perception of two product categories: electronic and electrical products made domestically, and similar products made in the U.S., Japan, South Korea, Germany and Britain. He revealed that domestic-made products were rated lower than those from foreign nations. Manrai et al.'s (1997) research examined the COO effect on product categories in 21 nations. The research demonstrated that product-category evaluations were highest for developed and industrialized nations, followed by newly industrialized nations, and finally, developing nations. Klenosky et al. (1996) analyzed the COO effect on Czech Republic consumers for two product categories, color television sets, and automobiles made by Western firms. Just as in other researched nations, Czech consumers showed COO sensitivity for different product categories. Elliott and Cameron (1996) conducted shopping mall intercept surveys of Australian consumer attitudes toward domestic product categories compared to similar products made in Japan, South Korea, Germany, the Philippines, the U.K., and the U.S. Results suggested that Australian consumers preferred domestically made products.

Though these studies are diverse both in focus and interest, they indicate a connection between COO perception and product quality. This perception is affected by several factors including the demographic and geographic characteristics of the consumers, perceived technical expertise of the $\mathrm{COO}$, the economic state of the consumer's nation, and the general perception of the item.

\section{4}

International Journal of Management Science and Business Administration, vol. 2, issue 10, pp. 44-47, September 2015 


\section{Country-of-Origin and Consumer Characteristics}

A review of the pertinent literature shows that research supports the fact that consumers' demographic characteristics have an effect on consumers' perceptions of domestic and imported products. A research study by Zbib et al. (2010) examined the country-of-origin perceptions with respect to the global snack food industry in the country of Lebanon. The study results showed that consumers' demographic characteristics do affect country-oforigin perceptions. $\mathrm{n}$ other words, there are demographic differences in the evaluation of global snack food products.

Scholars, such as Wall et al. (1988) and Schooler (1971), reported that age factor does affect consumers' evaluations of a product. Specifically, younger shopping consumers have more favorable evaluations of imports/foreign products in comparison to older consumers. Wall and Heslop (1986) reported that consumers with higher income prefer imports / foreign products. Additionally, McLain and Sternquist (1991) study findings show that there is a relationship between age and ethnocentrism (i.e., xenophobia).Older consumers are more ethnocentric / xenophobia than younger consumers. However, Han (1988) and McLain and Sternquist (1991) found no relationship between consumer income level and ethnocentrism. On the other hand, Han (1988) study results demonstrate that there is a connection between gender of the consumers and country of origin. Specifically, female consumers have a more tendency not to purchase foreign products/imports. McLain and Sternquist (1991) did report a relationship between consumers' education level and unfavorable attitudes toward imported products (i.e., ethnocentrism).Particularly, consumers with lower education level tend to be more ethnocentric than other shopping consumers with higher education level.

Many researchers have investigated the antecedents of COO evaluations (e.g., Apil and Kaynak, 2010; Roth and Diamantopoulos, 2009; Sohail, 2005; Insch and McBride, 2004; Balabanis and Diamantopoulos, 2004; Laroche et al., 2005; Chinen et al., 2000; Verlegh and Steenkamp, 1999; Klein et al., 1998; Hussein, 1997). However, the majority of consumer behavior frameworks and models were developed from the perspective of Western nations, predominantly United States consumers. While there has been some interest among scholars concerning the crosscultural aspects of $\mathrm{COO}$, efforts mainly have been confined to Asian nations. Few studies have focused on Latin American and Mediterranean nations, and fewer still focus on North African nations. This leaves an incomplete understanding of the effects of COO.

This study works to address the gap by assessing the interactions between $\mathrm{COO}$ and consumer decision-making processes in Morocco, an emerging market, and non-Western Mediterranean country and culture. By relating product categories to nations, this study offers insight into Moroccan-consumer-spending-preferences that may be used as a research benchmark for other non-Western countries, and provide product marketers with valuable information about consumer behavior.

\section{Design and Study}

The research goal was to examine if demographic characteristics such as age and gender make a difference in the $\mathrm{COO}$ influence for product categories within Morocco. Data for this research were collected mainly through a consumer survey. The Back Translation Method was used to translate the research instrument from English to French for the Moroccan sample. The Back Translation Method is considered highly effective in international marketing and business research (Kumar, 2000). Prior to administering the survey, a pre-test of the questionnaire was conducted for a small group of respondents. The results were satisfactory. The structure of the questionnaire allowed the respondents to rate all stimuli: 17 countries and nine categories, one at a time. This format has proven to be stable over time (Jaffe and Nebenzahl, 1984), and is consistent with the format used in previous country image studies (Roth and Romeo, 1992).

In our research study, data were gathered via the mall intercept approach in Rabat and Casablanca, Morocco. The two cities were selected because they are major metropolitan and urban centers. The cities of Rabat and Casablanca are also significant commercial and economic / trade centers in the country of Morocco. Furthermore, Rabat and Casablanca are generally considered representative of Morocco regarding Consumers' purchases situation of both domestic and imported/foreign goods and services. The surveys were distributed to consumers at shopping centers in a similar manner used by previous researchers (e.g., Hornik and Ellis, 1989).

\section{Results}

Univariate analysis of variance (ANOVA) was conducted on the data. Age was shown to interact with the impact of $\mathrm{COO}$ with regard to purchasing decisions regarding products from more industrialized / economically advanced 
nations, compared to products from less economically advanced/industrialized nations. As these findings demonstrated, $\mathrm{COO}$ does influence product category evaluation.

\section{Discussion and Implications}

These results have managerial implications in assisting multinational organizations in their market segmentations and positioning strategies. Specifically, they can segment the market of Morocco and other African and Mediterranean nations, on the basis of the sourcing countries. This presents an exciting challenge to businesses to coordinate business and marketing mix tactics, such as product policy, pricing, distribution, and communication strategies. These initiatives toward market openness and trade liberalization make Morocco an attractive destination for direct foreign investments by international firms. However, it is imperative for these businesses to understand how demographic factors such as gender, age, and education affect Moroccan / Mediterranean / North African (i.e., emerging market[s]) consumer evaluations of product categories.

\section{References}

- Apil, A. R. and Kaynak, E. (2010). Georgian consumers' evaluation of products sourced from European Union member countries: country-of-origin impact, International Journal of Commerce \& Management, 20(2), 167-187, CrossRef

- Balabanis, G. and Diamantopoulos, A. (2004). Domestic country bias, country-of-origin effects, and consumer ethnocentrism: a multidimensional unfolding approach, Academy of Marketing Science. Journal, 32(1), 80-95.

- Bandyopadhyay, S. and Banerjee, B. (2002). A country-of-origin analysis of foreign products by Indian consumers, Journal of International Consumer Marketing, 15(2), 85-109, CrossRef

- Chinen, K.; Enomoto, C.E. and Costley, D.L. (2000). The country-of-origin effect on Toyotas made in Japan, the USA and Mexico, Journal of Brand Management, 8(2), 139-148, CrossRef

- de Mooij, M. (2003). Convergence and divergence in consumer behaviour: implications for global advertising, International Journal of Advertising, 22 (2), 183-202.

- $\quad$ Eroglu, S.A. and Machleit, K.A. (1989). Effects of individual and product-specific variables on utilising country of origin as a product quality cue, International Marketing Review, 6(6), 27, CrossRef

- Felscherin, M. and Toncar, M. (2010). The effect of the country of manufacturing of automobiles: an experimental study of consumers' brand personality perceptions, International Marketing Review, 27(2), 164-178, CrossRef,CrossRef

- Han, C.M. (1988). The role of consumer patriotism in the choice of domestic versus foreign products, Journal of Advertising Research, 28(3), 25-32.

- Hornik, J. and Ellis, S. (1989). Strategies to Secure Compliance for a Mall Intercept Interview, Public Opinion Quarterly, 52(4), 539, CrossRef

- Hussein, R T.(1997). Jordanian consumers attitudes towards products of foreign origin vs domestic products. Journal of International Marketing and Marketing Research, 22(3), 157-163.

- Insch, G.S. andMcBride, J.B. (2004). The impact of country-of-origin cues on customer perceptions of product quality: A binational test of the decomposed country-of-origin construct, Journal of Business Research, 57(3), 256-265, CrossRef

- Klein, J.G., Ettenson, R. and Morris, M.D. (1998). The animosity model of foreign product purchase: An empirical test in the People's Republic of China, Journal of Marketing, 62(1), 89-100, CrossRef

- Klenosky, D.B, Benet, S.B, and Chadraba, P. (1996). Assessing Czech consumers' reactions to Western marketing practices: a conjoint approach, Journal of Business Research, 36(2), 189, CrossRef

- Kumar, V. (2000). International Marketing Research, Pearson/Prentice-Hall.

- Laroche, M., Papadopoulos, N., Heslop, L.A. and Mourali, M. (2005). The influence of country image structure on consumer evaluations of foreign products, International Marketing Review, 22(1), 96-115, CrossRef

- McLain, S. and Sternquist, B. (1991). Ethnocentric consumers: do they buy American?, Journal of International Consumer Marketing, 4(1/2), 39-57.

- Manrai, L.A., Manrai, A. K., Lascu, D-N., and Ryans, J.K. (1997). How green-claim strength and country disposition affect product evaluation and company image, Psychology \& Marketing, 14(5), 511-537, CrossRef

- Roth, M.S. and Romeo, J. B. (1992). Matching product category and country image perceptions: a framework for managing country-of-origin effects, Journal of International Business Studies, 23(3), 477, CrossRef

- $\quad$ Roth, K.P. and Diamantopoulos, A.. (2009). Advancing the country image construct, Journal of Business Research, 62(7), 726, CrossRef 
- Sohail, M.S..(2005). Malaysian Consumers' Evaluation of Products Made in Germany: the Country of Origin Effect. Asia Pacific Journal of Marketing and Logistics, 17(1), 89-105, CrossRef

- Tigli, H., Pirtini, S. and Erdem, Y.C. (2010). The perceived country of origin images in Turkey. The International Business \& Economics Research Journal, 9(8), 127-133, CrossRef

- Verlegh, P. W J. and Steenkamp, J-B. E M. (1999). A review and meta-analysis of country-of-origin research. Journal of Economic Psychology, 20(5), 521-546, CrossRef

- Wall, M. and Heslop, L.A. (1986). Consumer attitudes towards the quality of domestic and imported apparel and footwear, Journal of the Academy of Marketing Science, 14(2), 27-36, CrossRef

- Wall, M. and Heslop, L.A. (1986). Consumer attitudes towards the quality of domestic and imported apparel and footwear, Journal of the Academy of Marketing Science, 14(2), 27-36, CrossRef

- Wall, M., Heslop, L.A. and Hofstra, G. (1988). Male and female viewpoints of countries as producers of consumer goods, Journal of International Consumer Marketing, 1, 1-25, CrossRef

- Zbib, I.J.; Woodridge, B.R.; Ahmed, Z.U. and Sarkis, B. (2010). Selection criteria of Lebanese consumers in the global snack food industry: country of origin perceptions, The Journal of Consumer Marketing, 27(2), 139-156, CrossRef 